\title{
Use of DES-Treated Rats as an Animal Model for Assessment of Pituitary Adenoma Imaging Agents
}

\author{
CHARLOTTE A. OTTO, ${ }^{*}$ JOHN C. MARSHALL, RICARDO V. LLOYD, \\ PHILLIP S. SHERMAN, SUSAN J. FISHER, VALERI L. VALOPPI, \\ W. LESLIE ROGERS and DONALD M. WIELAND

\begin{abstract}
Department of Natural Sciences, University of Michigan-Dearborn, Dearborn, MI 48128 and Departments of Internal Medicine and Pathology, University of Michigan Medical Center,
\end{abstract} \\ Ann Arbor, MI 48109, U.S.A.
}

(Received 25 August 1985)

\begin{abstract}
Prolactin (PRL) secreting pituitary adenomas are the most common type of pituitary tumors. An imaging agent which specifically localized in prolactinomas would be of considerable clinical value for both initial detection and also for monitoring the effects of dopamine agonist therapy. Tritiated spiroperidol ( ${ }^{3} \mathrm{HSp}$ ) was selected for initial evaluation as a possible imaging agent based on: (1) demonstrated localization in the pituitary and (2) demonstrated binding to human PRL-secreting tumor tissue. DES was implanted in Fischer F344 rats and induced prolactinoma formation was evidenced by increased pituitary weight, elevated serum PRL levels and by an increase in the proportion of PRL-secreting cells in the pituitary. ${ }^{3} \mathrm{HSp}$ concentrations in pituitary and other tissues of DES-treated rats were assessed in female rats and correlation studies showed that a 5-fold increase in serum PRL was associated with a 6-fold increase in both pituitary weight and \% dose/organ accumulation of ${ }^{3} \mathrm{HSp}$. The number of pituitary $\mathrm{D}_{2}$ receptors per $\mathrm{mg}$ of protein in tissue homogenates was similar in both normal and DES-treated females. $\mathbf{A}$ blocking study with (+)-butaclamol demonstrated a $\mathrm{D}_{2}$ receptor-mediated component to ${ }^{3} \mathrm{HSp}$ localization. In summary, an animal model for prolactinoma was characterized. An assessment of ${ }^{3} \mathrm{HSp}$ accumulation indicates that radiolabelled spiroperidol shows excellent potential for detecting PRL-secreting tumors of the pituitary.
\end{abstract}

\section{Introduction}

Prolactin (PRL) secreting pituitary adenomas are the most common type of pituitary tumors. The high incidence of these tumors only became apparent within the past 9-10 years as a result of the development and general availability of a radioimmunoassay for measurement of PRL in serum. ${ }^{(1.2)}$ These tumors are common in females who usually present with galactorrhea, amenorrhea or infertility although other local effects such as visual disturbances from compression of the optic chiasma may be evident. It is now recognized that approximately $20-25 \%$ of all women with amenorrhea have prolactinomas. ${ }^{(3,4)}$

The detection of prolactinomas currently depends on physical symptoms, elevated serum PRL levels and abnormal CT scans of the sella turcica. However, other disorders such as pituitary cysts may present

\footnotetext{
* Author for correspondence.
}

with both elevated serum PRL and abnormal CT scans. ${ }^{(5)}$ Not only have surgically confirmed prolactinomas been found in patients with normal CT scans and with elevated serum PRL, ${ }^{(6-8)}$ but abnormal CT scans have a predictive value of only $22 \%$ for pituitary tumors in patients with no clinical history of pituitary disease. ${ }^{(9)} \mathrm{CT}$ scans do not functionally characterize tumors but merely indicate density changes which are presumed to reflect the presence of a tumor. Thus, diagnosis may be imprecise and often rests on the association of an elevated serum PRL level with a possible CT scan abnormality.

Prolactinomas have been demonstrated using $\left[{ }^{99 \mathrm{~m}} \mathrm{Tc}\right]$ pertechnetate. ${ }^{(10.11)}$ However, $\left[{ }^{99 \mathrm{~m}} \mathrm{Tc}\right]$ pertechnetate does not functionally characterize tumors but reflects increased vascularization and vascular permeability associated with tumor presence. Nuclear magnetic resonance (MR) has recently been evaluated for pituitary tumor imaging ${ }^{(12,13)}$ but MR also does not functionally characterize tumor type.

Thus, an imaging agent which specifically localizes 
in prolactinomas based on some functional characteristic of the tumor would be of considerable clinical value. Positive imaging of these tumors would enable a definite diagnosis of PRL-secreting adenoma to be made and this would represent an improvement over existing CT scans. Earlier detection may be possible and the effects of medical therapy (e.g. bromocriptine) on functional status and tumor size could be monitored in a serial manner.

Prolactin secretion appears to be largely under dopamine control. Dopamine, which is secreted into the hypophyseal portal blood, may inhibit PRL secretion by binding to receptors in the pituitary. ${ }^{(14)}$ The anterior pituitary is thought to contain exclusively postsynaptic $D_{2}$ receptors. ${ }^{(15,16)}$ Studies indicate that most human prolactinomas have intact dopamine receptor sites on the PRL-producing cells. ${ }^{(17}{ }^{19)}$ There are contrasting reports regarding the numbers of receptor sites in human prolactinomas. One study by Cronin et al. using spiroperidol found increased numbers of binding sites ${ }^{(18)}$ while Bression and colleagues using ${ }^{3} \mathrm{H}$-domperidone report decreased numbers. ${ }^{(19)}$ Further quantification studies using a uniform receptor concentration assay are necessary to clarify this point. Regardless, the increase in PRLsecreting cells (mammotrophs) in prolactinomas coupled with the presence of dopamine receptors capable of binding ${ }^{3} \mathrm{H}$-neuroleptics ${ }^{(15)}$ raises the possibility of receptor-mediated imaging of these tumors with a radiolabelled $D_{2}$ receptor antagonist.

Development of a suitable imaging agent depends not only on the synthesis of an appropriate radiopharmaceutical but on the availability of an animal tumor model with characteristics similar to human prolactinomas. A recent publication has shown that implantation of diethylstilbestrol (DES) in Fischer F344 rats resulted in the induction of PRL-secreting hyperplasia/tumor of pituitary tissue in almost all animals within 8-12 weeks after implantation. ${ }^{(20)}$ Treatment with estradiol had no effect on the affinity of the dopamine receptor for spiroperidol ${ }^{(21)}$ but the cffect of estrogens on the number of dopamine receptors in the rat pituitary is uncertain and has been reported to remain constant ${ }^{(21)}$ or to be reduced by approximately $50 \% .^{(22)}$ The presence of functioning pituitary dopamine receptors together with elevated serum PRL levels suggests that the DES-treated F344 rat is a suitable animal model for the assessment of potential imaging agents for prolactinomas.

As we have previously reported on the uptake of ${ }^{3} \mathrm{HSp}$ in the normal pituitary of Fischer F344 rats $^{(23)}$ and as ${ }^{3} \mathrm{HSp}$ binding to human PRL-secreting tumor tissue has been demonstrated, ${ }^{(18)}$ we evaluated ${ }^{3} \mathrm{HSp}$ in the DES-induced prolactinoma model rats. The concentration and retention of spiroperidol or its analogs in any pituitary tumor have not been determined.

Thus, we have studied ( 1 ) the time course of ${ }^{3} \mathrm{HSp}$ activity in tissues of DES-treated female F344 rats, (2) the effect of (+)-butaclamol on ${ }^{3} \mathrm{HSp}$ pituitary concentration, (3) the number of $D_{2}$ receptors in normal and DES-treated female rat pituitary, and (4) the correlations between ${ }^{3} \mathrm{HSp}$ concentration in the pituitary, serum prolactin levels and percent and number of PRL-producing cells in pituitary tissue of male and female rats treated with DES.

\section{Materials and Methods}

The following compounds or reagents were obtained from commercial sources: ${ }^{3} \mathrm{H}$-spiroperidol (25-30 Ci/mmol) (New England Nuclear), diethylstilbestrol (Aldrich Chemical Co.) avidin-biotin peroxidase complex (Vector Laboratory), diaminobenzidine hydrochloride, pargyline (Sigma Chemical Co.) (+)-butaclamol hydrochloride (Research Biochemicals Inc.). Dow Corning Silastic tubing and silicone adhesive type A were obtained commercially, as were the scintillation fluids used in counting, Ox-triti-scint (Romac) for tissue samples and ACS (Amersham) for binding assays.

Polyclonal antiserum to rat prolactin was obtained from the NIADDK. The NIADDK Pituitary Hormone Distribution Program supplied materials and protocols for the double antibody RIA for rat prolactin.

Fischer F344 rats, male and female, were purchased (Charles River). Animals were exposed to alternating $12 \mathrm{~h}$ periods of light and dark and received rat chow and water ad libitum during the study.

\section{Tumor model}

Prolactin secreting adenomas were induced by implanting DES-containing Silastic tubing s.c. into 30 day old rats under ether anesthesia through a small incision in the back. ${ }^{(20)}$ Control rats were implanted with empty Silastic tubing. The DESimplants were prepared as described except that $3 / 4$ in. lengths of tubing were used and these were filled with $10 \mathrm{mg}$ of DES. Both blank and DES-implants were soaked in $2 \%$ BSA solution for $24 \mathrm{~h}$ prior to implanting in the rats.

\section{Immunohistochemical staining}

The anterior and posterior pituitary lobes were removed separately and the anterior pituitary fixed in $3 \mathrm{~mL}$ of $10 \%$ formalin for $24 \mathrm{~h}$ at $23^{\circ} \mathrm{C}$ before being embedded in paraffin. Tissue sections were cut sagittally with a microtome $(5 \mu \mathrm{m})$ and stained with hematoxylin and eosin. Other sections were stained for PRL by immunohistochemical methods. ${ }^{(24)}$ After inhibiting endogenous peroxidase with $1 \%$ methanol- $\mathrm{H}_{2} \mathrm{O}_{2}$, tissues were washed in phosphate buffered saline (PBS), then treated with normal goat serum to suppress nonspecific binding for $30 \mathrm{~min}$. Rat anti-PRL serum (produced in rabbits and used at 1:1000 dilution) was applied for $1 \mathrm{~h}$ at $23^{\circ} \mathrm{C}$. The tissues were washed with PBS treated with 1:200 dilution of rabbit biotin-IgG made in goat for $30 \mathrm{~min}$, 
followed by PBS washes, then incubation with avidin-biotin peroxidase complex for $30 \mathrm{~min}$. Diaminobenzidine (DAB) was used as the chromogen (10 mg DAB in $50 \mathrm{~mL}$ PBS, pH 7.2 and $0.001 \%$ $\mathrm{H}_{2} \mathrm{O}_{2}$ ) for $5 \mathrm{~min}$.

Controls consisted of substituting normal rabbit serum for the primary antibody and absorbing each antibody with specific antigens for $24 \mathrm{~h}$ before performing the assay. Additional controls consisted of omitting biotin-IgG or avidin-biotin peroxidase complex. All of these controls resulted in no staining of the tissues. The number of cells staining positively for PRL was counted by systematically sampling the entire pituitary tissue using a $4 \mathrm{~mm}^{2}$ grid in the microscope ocular. A minimum of 1000 cells per slide were counted and scored as negative or positive if a brown-black reaction product was present in the cytoplasm.

\section{Serum prolactin assay}

Serum PRL was determined for all rats, male and female, control and DES-treated, using a published radioimmunoassay procedure. ${ }^{(25)}$

\section{$D_{2}$ receptor binding assay}

Female Fischer F344 rats under ether anesthesia were killed by decapitation. Normals were 8 weeks of age; DES-treated were sacrificed 4 weeks after implant. The pituitaries were rapidly removed and washed free of blood in cold saline. The anterior lobes were separated and stored at $-70^{\circ} \mathrm{C}$ until assayed. Pituitaries from both normal and DEStreated rats were assayed simultaneously. Tissue samples were homogenized at low speed with a Tekmar homogenizer using $30 \mathrm{vol}$ of cold buffer $(0.25 \mathrm{M}$ sucrose, $15 \mathrm{mM}$ Tris, $120 \mathrm{mM} \mathrm{NaCl}, 5 \mathrm{mM} \mathrm{KCl}$, $2 \mathrm{mM} \mathrm{CaCl}_{2}, 1 \mathrm{mM} \mathrm{MgCl}, 0.1 \mathrm{mM}$ EDTA, ${ }^{(32)} 2 \mu \mathrm{M}$ pargyline, $0.1 \%$ ascorbate, $\mathrm{pH} 7.4,25^{\circ} \mathrm{C}$ ). The homogenate was centrifuged twice as described. ${ }^{(21)}$ The final pellets were resuspended in Tris buffer (as above but omitting sucrose) and incubated for $10 \mathrm{~min}$ at $37^{\circ} \mathrm{C}$. The homogenates were then assayed for protein content ${ }^{(26)}$ and diluted with buffer to a final concentration of about $0.2 \mathrm{mg}$ protein $/ 100 \mu \mathrm{L}$.

For binding studies, $600 \mu \mathrm{L}$ samples were prepared in triplicate as described by Cronin and Weiner. ${ }^{(27)}$ Assays contained about $0.2 \mathrm{mg}$ protein. Membrane bound ${ }^{3} \mathrm{HSp}$ was separated by rapid filtration $(<5 \mathrm{~s})$ under vacuum over Schleicher \& Schuell No. 34 glass fiber filters and washed with $3 \times 4 \mathrm{~mL}$ cold Tris buffer. The filters were placed in scintillation vials and $3 \mathrm{~mL}$ scintillation fluid added. The samples were stored until translucent, then counted. All values were corrected for background.

Specific binding was defined as the total counts of ${ }^{3} \mathrm{HSp}$ minus the counts obtained in the presence of 1000-fold excess of $(+)$-butaclamol (pharmacologically active form). Scatchard analysis was performed to determine the apparent dissociation constant $K_{\mathrm{D}}$, and the maximal number of receptor sites, $B_{\max }$, for both normal and DES-treated pituitary.

\section{Tissue distribution studies}

DES-treated. Female Fischer F344 rats were implanted with DES as described above and sacrificed 4 weeks later. Tissue distribution studies were performed as described ${ }^{(23)}$ at $5 \mathrm{~min}$ and at 1 and $2 \mathrm{~h}$ post injection.

$(+)$-Butaclamol treated. Female rats implanted with DES were treated with $(+)$-butaclamol ( $2 \mathrm{mg} / \mathrm{kg}, n=6$, and $5 \mathrm{mg} / \mathrm{kg}, n=6$ ) $45 \mathrm{~min}$ prior to ${ }^{3} \mathrm{HSp}$ injection $(25 \mu \mathrm{Ci})$. Tissue distribution studies were performed as described at $t=1 \mathrm{~h}$ post ${ }^{3} \mathrm{HSp}$ injection.

\section{Correlation studies}

Protocol. Correlation studies were similarly performed on male and female rats. Thirty day old Fischer F344 rats (12 per group for each time period of 4 and 8 weeks) were implanted with blanks or DES. After 4 weeks for female rats, and after 4 and 8 wecks for male rats, the animals were separated into two groups of six animals and treated as follows. All animals were killed by decapitation, pituitaries removed and blood collected. Serum was kept frozen until use for PRL assay. The uteri of all female rats were removed, cleaned of fat, connective tissue and excess fluid and weighed. Six were treated as described above for tissue distribution studies. Six pituitaries were fixed for determination of the percentage of PRL-producing cells by immunohistochemical staining.

\section{Results \\ Effects of DES treatment}

The effects of DES on uterine and pituitary weight were determined. Uterine weight was $320 \pm 60 \mathrm{mg}$ for $10 \mathrm{mg}$ DES implanted for 4 weeks. This is comparable to $250 \mathrm{mg}$ reported for 4 weeks of treatment with $5 \mathrm{mg}$ DES $^{(20)}$ As expected, pituitary weights also increased and are presented in Table 3. For both males and females, the $10 \mathrm{mg}$ dosage of DES used resulted in higher pituitary weights than reported after $5 \mathrm{mg}$ DES treatment. ${ }^{(20)}$

The induction of PRL-secreting tumor was verified by the increase in weight of the anterior pituitary, by the elevation of serum PRL levels and by an increase in the numbers of PRL-secreting cells. In both male and female rats, the increase in PRL-secreting cells was uniformly distributed in the anterior pituitary. Figures $1 \mathrm{~A}$ and $\mathrm{B}$ are examples of pituitary tissue from normal and DES-treated female rats after immunohistochemical staining.

\section{Time course in DES-treated rats}

The concentration data of ${ }^{3} \mathrm{H}$-activity in various tissues from DES-treated rats is compiled in Table 1. 
Table 1. ${ }^{3} \mathrm{H}$-spiroperidol activity levels in DES-treated female rats ${ }^{\mathrm{a} . \mathrm{b}}$

\begin{tabular}{|c|c|c|c|}
\hline & \multicolumn{3}{|c|}{ Time } \\
\hline & $5 \min$ & $1 \mathrm{~h}$ & $2 \mathrm{~h}$ \\
\hline Anterior pituitary & $0.29: \pm 0.046$ & $0.321 \pm 0.014$ & $0.224 \pm 0.035$ \\
\hline Posterior pituitary & - $^{c}$ & $0.220 \pm 0.053$ & $0.097 \pm 0.029$ \\
\hline Uterus & $0.144 \pm 0.017$ & $0.123 \pm 0.003$ & $0.131 \pm 0.016$ \\
\hline Blood & $0.026 \pm 0.004$ & $0.017 \pm 0.002$ & $0.021 \pm 0.005$ \\
\hline
\end{tabular}

Over a time span from $5 \mathrm{~min}$ to $2 \mathrm{~h}$, the concentration in anterior and posterior pituitary, uterus and blood was approximately constant for both normal (data from Ref. 23) and DES-treated female rats. In DEStreated animals, anterior pituitary values were approximately 10 times that seen in other tissues.

The posterior pituitary could usually be visually distinguished from the anterior pituitary at 4 weeks after DES treatment in female rats. However, in female rats implanted with $10 \mathrm{mg}$ DES and sacrificed 8 weeks later, the tumors of all rats $(n=9)$ appeared necrotic and hemorrhagic. Concentration data in such tumors is of questionable validity so further evaluation was not performed. The posterior pituitary could not be distinguished from anterior pituitary in these rats.

\section{Butaclamol blocking study}

DES-treated female rats were pretreated with two dosages of (+)-butaclamol -2 and $5 \mathrm{mg} / \mathrm{kg}$. Results were similar for all tissues examined at both dosage levels and only percent $\mathrm{kg}$ dose $/ \mathrm{g}$ values for $2 \mathrm{mg} / \mathrm{kg}$ are presented in Table 2.

\section{$D_{2}$ receptor binding assay}

Scatchard analysis of ${ }^{3} \mathrm{HSp}$ specific binding to
Table 2. ${ }^{3} \mathrm{H}$ spiroperidol activity for (1)-butaclamol treated rats and percent reduction relative to controls, ${ }^{\mathrm{a}, \mathrm{b}}$

\begin{tabular}{lcc}
\hline Tissue & $\% \mathrm{~kg}$ dose $/ \mathrm{g}$ & $\%$ Reduction $^{\mathrm{c}}$ \\
\hline Anterior pituitary & $0.232 \pm 0.014$ & $28 \pm 7$ \\
Posterior pituitary & $0.238 \pm 0.055$ & - \\
Uterus & $0.079 \pm 0.002$ & $36 \pm 4$ \\
Blood & $0.016 \pm 0.001$ & - \\
\hline
\end{tabular}

$a_{n}=6$, Fischer F344 rats implanted with $10 \mathrm{mg}$ DES. Rats injected with (+)-butaclamol $(2 \mathrm{mg} / \mathrm{kg}) 45 \mathrm{~min}$ prior to ${ }^{3} \mathrm{HSp}$ injection $(25 \mu \mathrm{Ci})$. Sacrifice at $t=1 \mathrm{~h}$ post ${ }^{3} \mathrm{HSp}$ injection.

${ }^{b}$ Data as $\% \mathrm{~kg}$ dose $/ \mathrm{g}$, mean $\pm \mathrm{SEM}$.

'Percent relative to $\% \mathrm{~kg}$ dose $/ \mathrm{g}$ at $t=1 \mathrm{~h}$ for DES-treated rats (data in Table 1). Only statistical differences are listed.

anterior pituitary homogenates from normal and DES-treated female rats was performed. The apparent $K_{\mathrm{D}}$ is $0.15 \pm 0.06 \mathrm{nM}$ for normals and $0.19 \pm 0.08$ for DES-treated animals. The maximum number of $\mathrm{D}_{2}$ receptor sites $\left(B_{\max }\right)$ was also similar for normal $(71 \pm 13 \mathrm{fmol} / \mathrm{mg}$ protein) and DES-treated rats $(63 \pm 11)$.

\section{Correlation studies}

The relationship between serum PRL levels and the percent of PRL-secreting cells present in control and DES-implanted male and female rats is presented in Table 3. The increase in serum PRL levels to

Table 3. Correlation between serum prolactin levels, anterior pituitary weights, percent prolactin secreting cells and ${ }^{3} \mathrm{H}$-spiroperidol concentration at $t=1 \mathrm{~h}$ post injection ${ }^{\mathrm{B}}$

\begin{tabular}{|c|c|c|c|c|c|}
\hline & & \multicolumn{2}{|c|}{ Male } & \multicolumn{2}{|c|}{ Female } \\
\hline & & Control & DES & Control & DES \\
\hline $\begin{array}{l}\text { Serum prolactin } \\
(\mathrm{ng} / \mathrm{mL})\end{array}$ & $\begin{array}{l}4 w k \\
8 w k\end{array}$ & $\begin{array}{r}93 \pm 10 \\
180 \pm 27\end{array}$ & $\begin{array}{l}1170 \pm 110 \\
3600 \pm 340\end{array}$ & $506 \pm 139$ & $2500 \pm 199$ \\
\hline $\begin{array}{l}\text { Anterior pituitary } \\
\quad(\mathrm{mg})\end{array}$ & $\begin{array}{l}4 w k \\
8 w k\end{array}$ & $\begin{array}{l}5.18 \pm 0.37 \\
5.26 \pm 0.3^{b}\end{array}$ & $\begin{array}{c}21.1 \pm 3.0 \\
107 \pm 17\end{array}$ & $5.41 \pm 0.75$ & $33.81 \pm 2.80$ \\
\hline $\begin{array}{l}\text { Percent prolactin } \\
\text { secreting cells }\end{array}$ & $\begin{array}{l}4 w k \\
8 w k\end{array}$ & $\begin{array}{l}14.4 \pm 1.4 \\
15.2 \pm 0.8^{d}\end{array}$ & $\begin{array}{l}35.7 \pm 2.2 \\
46.4 \pm 1.8^{d}\end{array}$ & $32.3 \pm 1.4$ & $79.7 \pm 1.0$ \\
\hline $\begin{array}{l}\% \mathrm{~kg} \text { dose } / \mathrm{g} \\
\text { Anterior pituitary } \\
\text { Posterior pituitary } \\
\text { Anterior pituitary } \\
\text { Posterior pituitary }\end{array}$ & $\begin{array}{l}4 w k \\
4 w k \\
8 w k \\
8 w k\end{array}$ & $\begin{array}{l}0.219 \pm 0.013 \\
0.081 \pm 0.030^{\mathrm{d}} \\
0.482 \pm 0.084^{\mathrm{b}} \\
0.292 \pm 0.095^{\mathrm{b}}\end{array}$ & $\begin{array}{l}0.317 \pm 0.008 \\
0.182 \pm 0.012 \\
0.278 \pm 0.014\end{array}$ & $\begin{array}{l}0.363 \pm 0.022 \\
0.254 \pm 0.038\end{array}$ & $\begin{array}{l}0.311 \pm 0.140 \\
0.220 \pm 0.053\end{array}$ \\
\hline $\begin{array}{l}\% \text { dose/organ } \\
\text { Anterior pituitary } \\
\text { Posterior pituitary } \\
\text { Anterior pituitary } \\
\text { Posterior pituitary }\end{array}$ & $\begin{array}{l}4 w k \\
4 w k \\
8 w k \\
8 w k\end{array}$ & $\begin{array}{l}0.008 \pm 0.001 \\
0.002 \pm 0.000 \\
0.011 \pm 0.001^{b} \\
0.002 \pm 0.000\end{array}$ & $\begin{array}{l}0.062 \pm 0.008 \\
0.003 \pm 0.006 \\
0.218 \pm 0.032\end{array}$ & $\begin{array}{l}0.016 \pm 0.002 \\
0.002 \pm 0.000\end{array}$ & $\begin{array}{l}0.093 \pm 0.010 \\
0.003 \pm 0.000\end{array}$ \\
\hline
\end{tabular}

${ }^{a} n=6$, Fischer $\mathbf{F} 344$ rats implanted at 30 days with $0.0 \mathrm{mg}$ DES (control) and $10.0 \mathrm{mg}$ DES, mean \pm SEM.

${ }^{b} n=3$.

sPercent per minimum of 1000 cells counted.

${ }^{\mathrm{d}} n=5$. 


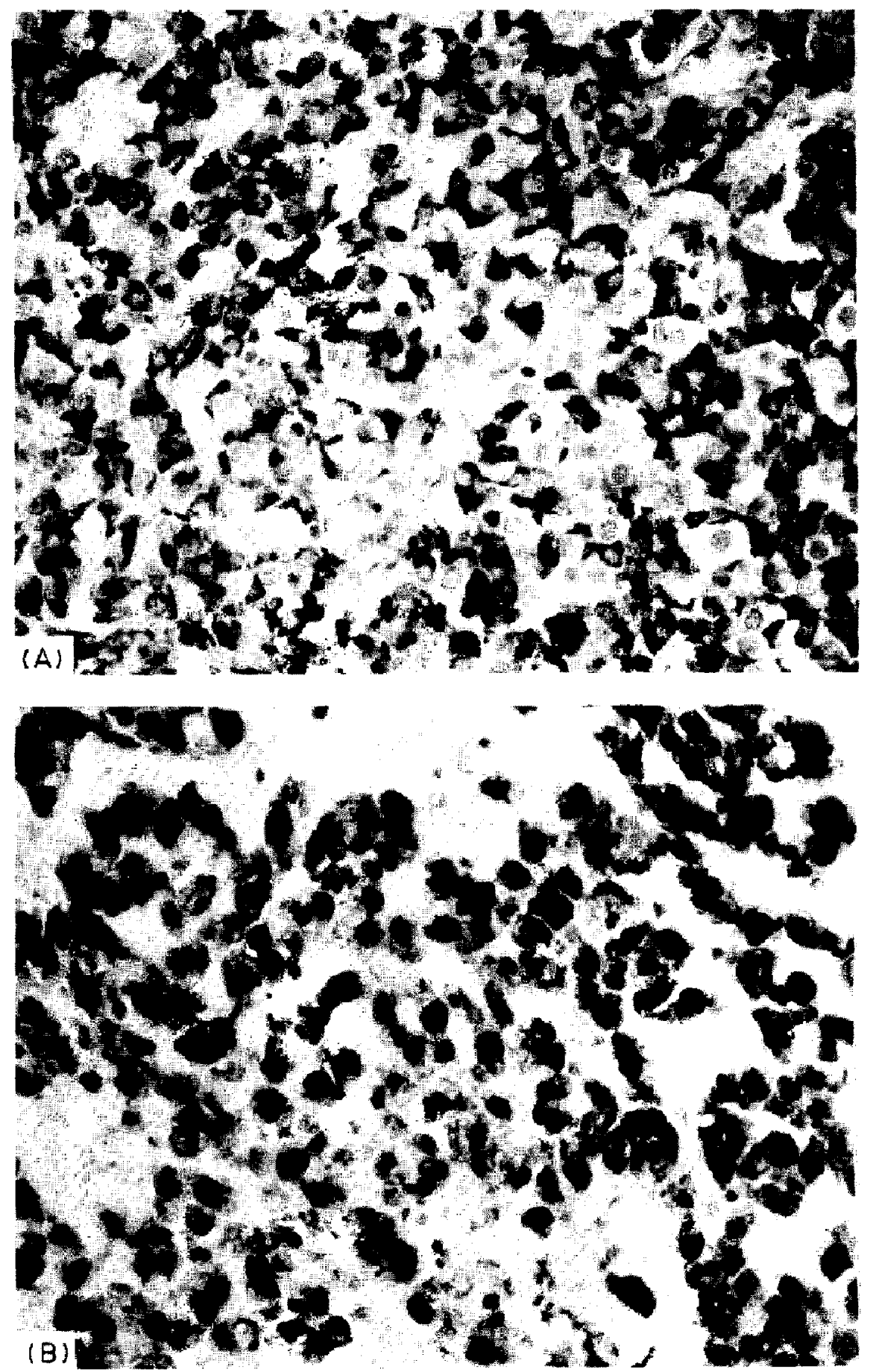

Fig. 1. (A) Normal anterior pituitary gland from a female ral stained for PRL by immunohistochemistry.

A black reaction product is present in the cytoplasm of PRL-producing cells. (Immunoperoxidase $\times 330$.)

(B) Pituitary gland from DES-treated female rat stained for PRL by immunohistochemistry. Most of the tumor cells contain immunoreactive PRL. (Immunoperoxidase $\times 330$.) 
$1170 \pm 110 \mathrm{ng} / \mathrm{mL}$ for males and to $2500 \pm 199$ for females was associated with a 2.5 fold increase in the percent of PRL-secreting cells in the anterior pituitary of both male and female rats at 4 weeks. When placed in conjunction with increasing pituitary weight, this increase in percent of PRL-secreting cells corresponds to a 10 fold increase in the total number of PRL-secreting cells for males and a 15 fold increase for females. Male rats were also evaluated at 8 weeks as the pituitary tumors, in contrast to females at 8 weeks, were smaller, less vascularized and did not appear hemorrhagic (see Time course in DES-treated rats above).

The tissue concintrations of ${ }^{3} \mathrm{H}$-spiroperidol are also presented in Table 3. Concentration values are presented as $\% \mathrm{~kg}$ dose $/ \mathrm{g}$, the normalized tissue concentration, and as $\%$ dose/organ which reflects the fraction of the dose administered which localized in the anterior pituitary. In male rats a 10 fold increase in serum PRL level is associated with an 8 fold increase in the \% dose/organ and a 4 fold increase in anterior pituitary weight. In female rats a 5 fold increase in serum PRL is associated with a 6 fold increase in \% dose/organ and a 6 fold increase in anterior pituitary weight. Figure 2 shows the correlation between \% dose/organ and serum PRL levels in male and female rats in graphic form.

The correlation between percent PRL cells with \% dose/organ and $\% \mathrm{~kg}$ dose $/ \mathrm{g}$ is also contained in Table 3. Percent dose/organ values in the posterior pituitary are minimally affected by treatment with DES (less than 2 fold increase) and are the same for male and female rats at all time intervals. Anterior pituitary values increased dramatically, as stated above. In sharp contrast to \% dose/organ increases, the $\% \mathrm{~kg}$ dose $/ \mathrm{g}$ values relative to control values remained approximately constant for males and females at 4 weeks and showed a $50 \%$ decrease in males at 8 weeks. It is interesting that the 6 fold increase in \% dose/organ for females and the 8 fold increase for males correlate with a 2.5 fold increase in the percent of PRL-producing cells for both female and male rats.

\section{Discussion}

Time course in DES-treated rats

The dissociation constants of ${ }^{3} \mathrm{HSp}$ from human anterior pituitary and from human PRL-secreting pituitary adenomas are similar $\left[K_{\mathrm{D}}=2.2 \pm 0.7\right.$ and $3.1 \pm 1.4 \mathrm{nM}$, respectively (mean $\left.\pm \mathrm{SEM}^{(18)}\right]$. The similarity in $K_{\mathrm{D}}$ suggests that the time course for ${ }^{3} \mathrm{HSp}$ uptake by tumor tissue may be the same as in normal tissue. Comparison of data in Table 1 with data from normal rats (See Table 1 in Ref. 23) shows that ${ }^{3} \mathrm{HSp}$ uptake appears to be constant from $5 \mathrm{~min}$ to $2 \mathrm{~h}$ in both normal and tumor pituitary tissue. Percent $\mathrm{kg}$ dose $/ \mathrm{g}$ in anterior pituitary is a normalized value and reflects concentration of injected radioactivity/g tissue. The data suggest that although the pituitary weight has increased 6 fold due to tumor, the concentration/g tissue has remained approximately constant. Because of the similarity in data between normal and DES-tumor induced rats, further time intervals were not evaluated.

\section{Butaclamol blocking study}

As with the time course results, the data obtained from rats pretreated with butaclamol are experimentally equivalent for both control ${ }^{(23)}$ and DESinduced tumor bearing rats. That is, the $28 \pm 7 \%$ reduction observed in anterior pituitary is lower than that reported for cortex and striatum. The reduction

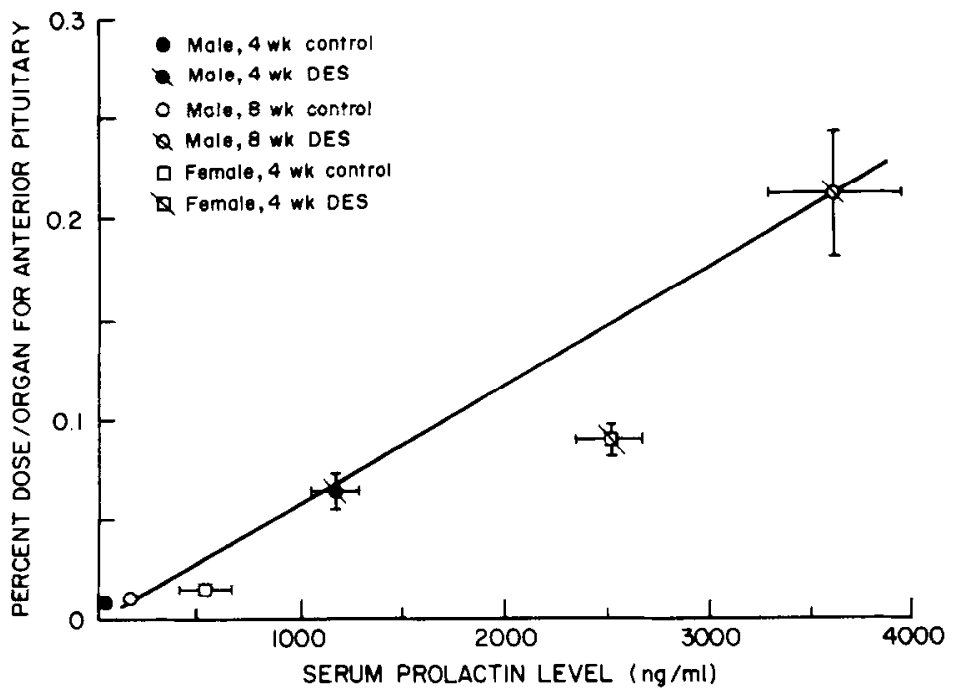

Fig. 2. Percent dose/organ vs serum prolactin level in male and female rats after treatment with DES and in controls. Sacrifice was at $1 \mathrm{~h}$ post injection. (Correlation factor $r=0.9987$.) 
in ${ }^{3} \mathrm{HSp}$ uptake is supportive that some concentration of ${ }^{3} \mathrm{HSp}$ is due to $\mathrm{D}_{2}$ receptor specific binding.

\section{$D_{2}$ receptor binding assay}

The $K_{\mathrm{D}}$ value observed for normal rats is similar to that reported using F344 male anterior pituitary, $0.10 \pm 0.04 \mathrm{nM}^{(28)}$ and other rat anterior pituitary tissue. ${ }^{(29-32)}$ Likewise the apparent $K_{\mathrm{d}}$ for DES-treated pituitary is comparable to values reported for estradiol treated adult male $\mathrm{F} 344$ rats: $0.12 \pm 0.02$ and $0.15 \pm 0.03 \mathrm{nM}$ for 15 and 90 days of estradiol treatment, respectively. ${ }^{(28)}$

The $B_{\max }$ values reported here are similar to those reported for male F344 rats. ${ }^{(28)}$ These data suggest that DES treatment did not significantly alter the observed $B_{\max }$ which is in agreement with data obtained using estrogen treated adult male F344 rats ${ }^{(28)}$ and adult female Sprague-Dawley rats, ${ }^{(21,32)}$ and contrasts with data obtained from female Wistar rats. ${ }^{(29)}$ $B_{\max }$ determination is in terms of $\mathrm{mg}$ pituitary protein and does not include any correction for the percent of PRL-secreting cells (see following discussion).

\section{Correlation study}

When $\%$ dose/mg pituitary is calculated by dividing \% dose/organ by anterior pituitary weight (data in Table 3), the value is $0.0024 \pm 0.0005 \%$ dose/mg and is independent of sex or length of DES treatment. This similarity suggests that, although pituitary weight increased, the relative uptake/mg tissue has remained constant. If one assumes that ${ }^{3} \mathrm{HSp}$ localization in the pituitary is dependent on at least an initial complex formation with the $\mathrm{D}_{2}$ receptor, then one might expect that the concentration of $\mathrm{D}_{2}$ receptors/mg tissue has also remained constant. Data presented earlier in $D_{2}$ receptor assay show that the concentration of $D_{2}$ receptors in DES induced rat prolactinoma is approximately the same as in controls. Consideration of the $D_{2}$ receptor concentration in connection with the (for females) 15 fold increase in the number of PRL-secreting cells suggests that the number of $D_{2}$ receptors per PRL-secreting cell has been reduced. The relationship between increases in $\%$ dose/organ and increases in the number of PRLsecreting cells may also be interpreted as support for reduction of number of $D_{2}$ receptors per cell. For males, the number of PRL cells increase about 1.3 times faster than \% dose/organ; for females, this rate of increase is about 2.7. Although the relationship differs for males and females, apparently uptake as $\%$ dose/organ is not directly correlated with increasing number of PRL cells.

In general terms, for both male and female rats at 4 weeks, increasing serum PRL levels were accompanied by increases in the percent and number of PRL-secreting cells and by increases in pituitary size. These increases correlate with increasing \% dose/organ values. For males and females, there appear to be different rates of increase of \% dose/organ ( 8 fold for males, 6 fold for females), serum PRL (12 fold for males, 5 fold for females), and number of PRL-secreting cells (10 fold vs 15 fold).

\section{Prolactinoma imaging assessment}

The goal of the present work was to develop an animal model that could be used to screen radiotracers for their potential as mammotroph (prolactinoma) imaging agents. Based on the observed uptake in rats in DES induced prolactinomas and in normal tissue, radiolabelled spiroperidol shows excellent potential for detecting both PRL-secreting pituitary tumors and normal pituitary. Since the size of the pituitary in humans is at the resolution limit of various brain imaging instruments, early presence of a prolactinoma would need to be inferred from an uptake measurement which could best be performed using single photon tomography. In the DESstimulated pituitary, both pituitary mass and density of PRL-secreting cells increased with the net effect of increasing the uptake per organ by a factor ranging from a low of 5.8 for female rats at 4 weeks to a high of 19.8 for males at 8 wecks. It is highly likcly that increases of this magnitude will lie well outside the normal variation for humans and could be detected even at count rates ranging from 12 to $70 \mathrm{cpm}$ predicted in a worst case analysis of a hypothetical normal pituitary. ${ }^{(23)}$ Since the pituitary is below the brain and since it is surrounded by bone, imaging the pituitary will be similar to imaging a point source in background. One can therefore expect good results in uptake measurements.

Future efforts will use this model and a series of other radiolabelled $\mathrm{D}_{2}$ agonists and antagonists. In other studies, attempts will be made to induce pituitary adenomas in larger animals to permit direct scintigraphy evaluations.

Acknowledgements - Research was supported jointly by Grant No. RR 05383, Biomedical Research Support Grant from NIH, by a Biomedical Research Support Grant to the Vice-President for Research at the University of Michigan from NIH, and by a grant from Phoenix Memorial Laboratory at the University of Michigan.

The authors thank Larry Brown, Kristina Schmidt, Alice Istock, Melissa Schiff and Laura Herbon for technical assistance and Linder Markham, Irene Sayer and Elizabeth Van Wormer for help in preparing the manuscript. We are indebted to Dr Brahm Shapiro for helpful discussions.

\section{References}

1. Hwang P., Guyda H. and Friesen H. Proc. Natl. Acad. Sci. USA 68, 1902 (1971).

2. Sinha Y. N., Selby F. W., Lewis U. J. et al. J. Clin. Endocrinol. Metab. 36, 509 (1973).

3. Franks S., Murray M. A. F., Jequier A. M. et al. Clin. Endocrinol. 4, 597 (1975).

4. Jacobs H. S., Franks S., Murray M. A. F. et al. Clin. Endocrinol. 5, 439 (1976).

5. Baskin D. S. and Wilson C. B. J. Neurosurg. 60, 8 (1984).

6. Tindall G. T., McLanahan C. S. and Christy J. H. J. Neurosurg. 48, 849 (1978). 
7. Cowden E. A., Ratcliffe J. G., Thomson J. A. et al. Lancet 1, 1155 (1979).

8. Randall R. V., Laws E. R. Jr, Abboud C. F. et al. Mayo Clin. Proc. 58, 108 (1983).

9. Burrow G. N., Wortzman G., Rewcastle N. B. et al. $N$. Engl. J. Med. 304, 156 (1981).

10. Britton K. E., Shapiro B., Hawkins L. A. et al. Nucl. Med. 18, 370 (1981).

11. Britton K. and Shapiro B. J. Roy. Soc. Med. 74, 667 (1981).

12. Oot R., New P. F. J., Buonanno F. S. et al. Am. J. Neuroradiol. 5, 131 (1984).

13. Osbakken M., Gonzales J. and Page R. J. Nucl. Med. 25, P7 (1984).

14. Terry L. C. In Hormone-Secreting Pituitary Tiumors. (Ed. Givens J. R.) pp. 27-44. (Year Book Medical Publishers, Chicago, 1982).

15. Seeman P. Pharmacol. Rev. 32, 229 (1981) and references therein.

16. Labrie F., DiPaolo T., Raymond V. et al. In Ergot Compounds and Brain Function. Neuroendocrine and Neuropsychiatric Aspects. (Ed. Goldstein M. et al.) pp. 217-227. (Raven Press, New York, 1980).

17. Bethea C. L., Ramsdell J. S., Jaffe R. B. et al. J. Clin. Endocrinol. Metab. 54, 893 (1982).

18. Cronin M. J., Cheung C. Y., Wilson C. B. et al. J. Clin. Endocrinol. Metab. 50, 387 (1980).
19. Bression D., Brandi A. M., Martes M. P. et al. J. Clin. Endocrinol. Metab. 51, 1037 (1980).

20. Wiklund J., Wertz N. and Gorski J. Endocrinol. 109, $1700(1981)$

21. Dipaolo, T., Carmichael, R., Labrie, F. et al. Mol. Cell Endocrinol. 16, 99, (1979) and references therein.

22. Cronin M. J., Cheung C. Y., Beach J. E. et al. In Central and Peripheral Regulation of Prolactin Function. (Eds MacLeod R. M. and Scapagnini U.) pp. 43-58. (Raven Press, New York, 1980).

23. Otto C. A., Sherman P. S., Fisher S. J. et al. Nucl. Med. Biol. 13, 533 (1986).

24. Lloyd R. V. Am. J. Pathol. 113, 198 (1983).

25. Niswender G. D., Chen C. L., Midgley A. R. et al. Proc. Soc. Exp. Biol. Med. 130, 793 (1969).

26. Bradford M. M. Anal. Biochem. 72, 248 (1976).

27. Cronin M. J. and Weiner R. I. Endocrinol. 104, 307 (1979).

28. Andre J., Marchisio A. M., Morel Y. et al. Biochem. Biophys. Res. Commun. 106, 229 (1982).

29. Heiman M. L. and Ben-Jonathan N. Endocrinol. 111, 1057 (1982)

30. Stefanini E., Devoto P., Marchisio A. M. et al. Life Sci. 26, $583(1980)$.

31. Schaeffer J. M. and Hsueh A. J. W. J. Biol. Chem. 254, 5606 (1979).

32. DiPaolo T. and Falardeau P. Biochem. Biophys. Res. Commun. 123, 312 (1984). 